\title{
Metajornalismo com os diabos e o obsceno em João do Rio
}

\author{
Gutemberg Medeiros
}

Resumo: Na primeira década do século XX é implantado no Brasil o moderno jornalismo dos Estados Unidos e da Europa, e a imprensa nacional propõe reflexões sobre as práticas jornalísticas no país em diferentes produções textuais, antes mesmo de o papel do ombudsman ser estabelecido; um movimento chamado neste artigo de metajornalismo. São discutidas transformações na semiosfera midiática que trazem subsídios para reflexões sobre memória social e história do jornalismo brasileiro, por meio de uma análise de reportagens da Gazeta Mercantil e de textos de João do Rio.

Palavras-chave: metajornalismo; Gazeta Mercantil; João do Rio

Abstract: Meta-journalism and the obscene in João do Rio - Modern journalism originating from the United States and Europe is implemented in Brazil in the first decade of the twentieth century, and the national press proposes reflections about journalistic practices in the country in different textual productions, even before the role of the ombudsman is established, in a movement this article calls meta-journalism. This article discusses transformations in the mediatic semiosphere that underpin reflections on social memory and on the history of Brazilian journalism, based on an analysis of articles published by the newspaper Gazeta Mercantil and of texts authored by João do Rio.

Keywords: metajournalism; Gazeta Mercantil; João do Rio

A primeira década do século XX foi decisiva para o Brasil quando vários elementos da modernidade aqui aportaram em meio ao flagrante atraso em relação às suas matrizes norteamericana e europeia. Os braços dessa modernidade se estabeleceram na implantação de um jornalismo moderno e da grande reforma urbana do Rio de Janeiro.

A grande mudança ocorrida na imprensa da época foi acompanhada por uma arena de vozes - concordantes, discordantes ou polêmicas no sentido bakhtiniano 
- que a debateram intensamente. Tal polêmica foi em jornais e outros suportes, que chamamos de metajornalismo - quando o jornalismo vira tema de si próprio. Esse debate foi destacado, especialmente, no romance de Lima Barreto Recordações do escrivão Isaías Caminha e em peças teatrais de João do Rio (MEDEIROS, 2009).

Aqui expomos três momentos desse movimento de metajornalismo que se estabeleceu na semiosfera ${ }^{1}$ midiática. O primeiro com a matéria institucional "Como se faz um jornal de hoje" publicado na Gazeta de Notícias, de 1907, em que o veículo se apresenta como o mais moderno da época e se expõe na qualidade de suporte principal do novo jornalismo que se constitui na época. Um dos grandes destaques é a nova figura desse cenário, o repórter, como mão de obra qualificada a gerar ao jornal moderno o seu principal produto: a notícia.

Os dois outros momentos são marcados por textos de João do Rio que problematizam o lugar e a importância do repórter no jornalismo moderno. O primeiro texto foi publicado também em 1907 na sua coluna "Cinematographo"2, na mesma Gazeta de Notícias, e estabelecia polêmica velada com o órgão ao especificar como essa mão de obra se qualificou, mas continuavam os mesmos péssimos salários da imprensa anterior; o segundo, intitulado "Profissões" (Revista da Semana, 1916), tratava de outros aspectos desse novo profissional.

\section{Jornal é pauta de jornal}

Pode-se pensar o início do metajornalismo após a Segunda Guerra Mundial com o estabelecimento do ombudsman sueco ou em 1967, quando o jornal norte-americano Louisville Courrier-Journal cria a figura do "provedor do leitor" nesse molde europeu e a grande imprensa passa a adotar tal postura. "O aparecimento deste mecanismo [... são] metajornalísticas, na medida em que confinam uma espécie de jornalismo sobre o jornalismo [...] no fundo, a admissão, ainda que contrariada por grupos de profissionais, de que o jornalismo não tem por que ser um ofício de privilégios destacados" (OLIVEIRA, 2007, p. 17).

Porém, antes dessa formalização, o jornalismo tinha como tema a si mesmo de maneira não frequente como uma coluna, mas com certa regularidade. Até onde alcançou

1 A semiosfera foi um conceito elaborado por lúri Lotman, com base em artigo publicado originalmente em 1984, para expressar um determinado espaço semiótico e a relação espaço-temporal entre diversos textos e sistemas sígnicos que os compõem. A semiosfera é um continuum semiótico de textos ou objetos ou formações semióticas de vários tipos e níveis de organização (LOTMAN, 1996, p. 22 e ss.). Um dos elementos da semiosfera mais importantes é o de fronteira. A fronteira une duas esferas da semiosis, desde a autoconsciência semiótica - autodescrição em um metanível da semiosfera dada (ibidem, p. 28). A fronteira é um domínio de processos semióticos acelerados que ocorre mais na periferia e se dirige às estruturas nucleares para, possivelmente, desalojá-las.

2 A coluna "Cinematographo", sob assinatura de Joe, caracterizou-se por ocupar uma página colorida, com ilustração do suplemento dominical da Gazeta de Notícias. Ela foi "dividida em tópicos com o nome dos dias da semana, em forma de diário pessoal à moda da imprensa parisiense, porém carioquíssima no raciocínio e no linguajar - cabia de tudo: crônica literária; crônica social e de costumes; crítica literária e teatral; perfis de políticos, literatos e artistas; e confissões pessoais. Variedades, como as que eram apresentadas nos cinematógrafos da cidade, daí o nome" (RODRIGUES, 1996, p. 72) 
nossas pesquisas, Nelson Rodrigues provavelmente elaborou os dois momentos mais intensos de metajornalismo no Brasil nas peças Boca de ouro (1960) e Beijo no asfalto (1961). Após a estreia dessa peça, declarou:

\begin{abstract}
[...] todos estamos afetados por esta peça e ninguém que a veja poderá sentir-se alheio a ela, pois nos envolve a todos. Eu creio firmemente que vivemos numa floresta de papel impresso: somos modelados, condicionados pela imprensa. Em Beijo no asfalto é dramatizado e tratado como se fosse uma personagem da peça. Cria-se então uma mútua dependência: os leitores tornam-se vítimas do que leem nos jornais e estes tornam-se vítimas dos caprichos, das atitudes e reações de seus leitores (RIBEIRO, 1966, p. 384).
\end{abstract}

Em ampla tradição de metajornalismo no Brasil, nos focamos em dois momentos que foram expressos quando os debates sobre os rumos da imprensa se adensaram durante a implantação do moderno jornalismo, na primeira década do século XX.

\title{
Pela imprensa industrial
}

Um dos principais polemistas dessa nova ordem da comunicação foi João Paulo Alberto Coelho Barreto (1881-1921), mais conhecido pelo pseudônimo de João do Rio. Como jornalista, inicia em 1899 e, em 1903, ingressa na Gazeta de Notícias, sendo um dos introdutores do moderno jornalismo no Brasil ao realizar reportagens temáticas. Como em "As religiões do Rio", em que dá voz às perseguidas religiões afro-brasileiras.

João do Rio é também um símbolo paradoxal ao acusar o "espírito 'yankee" do novo jornalismo da época a corromper a literatura brasileira, levando os escritores ao sacrifício de suas penas a troco da sobrevivência cotidiana. Elysio de Carvalho ${ }^{3}$ o define como um dos mais importantes escritores da época e o denomina como caso exemplar "a serviço de uma imprensa industrial, que outra coisa não é o jornal moderno, exigente e dispersivo, que absorve toda a vida intelectual, inutilizando-a quase sempre" (CARVALHO, 1997, p. 83).

A importância de João do Rio ao ser considerado um dos primeiros repórteres foi destacado por Danton Jobim - um dos introdutores da segunda fase norte-americana na imprensa brasileira,

\section{[...] as grandes reportagens que João do Rio escreveu ainda hoje [1958] podem ser reeditadas [...] [as suas reportagens publicadas em livro] ficaram porque retratam a fisionomia de uma época, num estilo claro, direto e original; ficaram pelo que há de humano e permanente em toda boa literatura, não importando a sua finalidade e os temas escolhidos. Ficaram, enfim, porque escritor e jornalista coexistiram na personalidade de João do Rio (JOBIM, 1958, p. 35).}

3 Elysio de Carvalho (1880-1925) foi um dos mais respeitados polígrafos de sua geração, tendo escrito mais de quarenta livros. João do Rio o entrevistou na enquete "O momento literário" (Garnier, 1908, p. 256-273). 
Em 1907, João do Rio produz uma de suas mais importantes reportagens temáticas: "A alma encantadora das ruas", a maior aproximação desse jornalista com a pobreza que circundava o Rio de Janeiro da belle époque. Trata-se de textos publicados entre 1904 e 1907 na Gazeta de Notícias ou na Revista Kosmos. Para o historiador José Murilo de Carvalho:

Interioranos de um lado e "galegos" de outro vinham engrossar a multidão dos jornaleiros, domésticos, ambulantes, todo um leque de ocupações variadas. Engrossavam também o número de assaltantes, pivetes, jogadores, malandros e vagabundos em geral. Era um Rio subterrâneo, menos visível, mas que se vinculava umbilicalmente ao Rio oficial, subterrâneo. João do Rio descreveu melhor do que ninguém este lado da cidade sobretudo em sua coletânea de crônicas A Alma Encantadora das Ruas (CARVALHO, 1989, p. 77-79, grifo nosso).

O moderno jornalismo se estabeleceu definitivamente em 1907 e se constitui através do emprego de novas modalidades de textos para veicular notícias ou privilegiar informações derivadas de reportagens de campo, títulos em letras garrafais, intertítulos, charges, ilustrações e vinhetas em modernos parques gráficos e modelo industrial de produção até o regime rígido de distribuição, sob a égide do tempo.

Tal modernização pouco chegou ao âmago do departamento financeiro das empresas que viviam, em sua maioria, de recursos conseguidos junto ao Tesouro Nacional. Em evidente contraste ao alto padrão de vida de vários donos de jornais, os repórteres sobreviviam com baixos salários. Elevou-se o patamar das empresas em recursos materiais para compor esse novo jornal diário, mas nada mudou para essa emergente mão de obra qualificada. Isso passou a ser um dos temas em metajornalismo levado em jornal diário por João do Rio.

Antes da análise desse trabalho, é importante focalizar os elementos formais e empresariais dessa nova imprensa e expressos por um dos mais destacados jornais brasileiros, justamente onde João do Rio atuou na construção desse jornalismo moderno da época.

\section{Jornal pela voz do jornal}

Para Barbosa Lima Sobrinho ${ }^{4}$, um dos retratos mais fiéis da imprensa na capital da república, logo após a instauração do regime republicano, foi descrito pelo jornalista francês Max Leclerc. Reunindo doze grandes matérias investigativas na coletânea Cartas do Brasil, respondia pela editoria de política internacional do jornal parisiense Journal des Débats 5 e veio reportar como estava o país sob o novo regime.

4 Alexandre José Barbosa Lima Sobrinho (1897-2000) foi jornalista, advogado, ensaísta, historiador, professor e político. Colaborou nos jornais Diário de Pernambuco, Jornal do Commercio, Correio Brasilense, Jornal do Brasil e outros. Na Associação Brasileira de Imprensa, foi presidente de 1926 a 1927, 1930 a 1932, sendo presidente do Conselho Administrativo de 1964 a 1977 e novamente presidente de 1978 a 2000.

5 Publicado entre 1789 e 1944, foi um dos mais inovadores e influentes jornais diários na França. Entre os seus quadros, constaram François-René Chateaubriand, Alexandre Dumas (pai), Victor Hugo e Eugène Sue. 
Nas páginas dedicadas à imprensa local, o jornalista francês inicia com a pergunta: "Será justo, será prudente, julgar um povo pelos jornais que lê?" (LECLERC, 1942, p. 161). Os maiores jornais brasileiros, para Leclerc, são Jornal do Commercio e Gazeta de Notícias. Ele define o Jornal do Commercio como um Times londrino sem a "virilidade" deste nem seus leading articles ${ }^{6}$ de primeira página. Porém, seria “um bom depositório de fatos, conjunto útil de documentos" (idem, p. 163). Já a Gazeta de Notícias não registra passivamente os fatos, mas tenta conduzir a opinião pública pela construção opinativa.

Leclerc aponta que a principal falha no jornalismo brasileiro é ter espaços muito grandes - inclusive na primeira página - para propaganda e pouco ao editorial. Mais dedicado à arte de falar mal ou a dar publicidade a fatos de pouco interesse, enquanto os de repercussão mais ampla são desprezados a locais menos importantes na diagramação. O jornalismo moderno, o qual esse jornalista representa, é a editorialização da propaganda de produtos ou ideias. Mas "vender" jornal depende de informação apurada - a reportagem - para conduzir os gostos dos leitores e despertar as empresas para as oportunidades de negócios ou nichos de mercado a explorar.

Para Leclerc, em suma, o jornalista focado em economia aponta que a imprensa brasileira não sabe informar e encontra-se em fase amadora nos mais variados sentidos. É interessante observar que o jornalista desenha os jornais como uma linha de produção industrial, pois em suas palavras há a implicação de dois elementos primordiais e estritos: cadeia produtiva e uso do tempo.

Como levantamos em nossa pesquisa para a tese de doutorado, a grande mudança da semiosfera jornalística do Brasil ocorreu lentamente a partir do final do século XIX e estabilizou-se por volta de 1907. Percebemos tal estabilização, entre outros momentos, na matéria "Como se faz um jornal de hoje" sem assinatura, institucional da Gazeta de Notícias - o mesmo apreciado por Leclerc. Publicada em 2 de agosto de 1907, é construída na primeira pessoa do plural, quando o mais comum era o uso da terceira pessoa do singular - exceto em crônicas ou artigos em tom autoral.

Algumas características saltam aos olhos, especialmente o desenho da página, muito refinado para os textos blocados da época e ainda com poucas ilustrações. O título é inovador, brincando com "branco" (espaços vazios, como se diz no meio gráfico) em quase formato de escada descendente, convidando o olhar do leitor para a leitura.

Observamos a presença de oito fotografias acompanhadas de pequenos textos-legendas indicativos: "A sala de redacção", "O escriptorio da rua do Ouvidor" (sede), "Uma das salas das machinas" (gráfica), "A typografia às 8 da noite", "A sahida dos jornaes no edificio da rua Sete", "A Stereotypia" (outro setor da gráfica) e "A nova fachada do escriptorio".

Para a época, essa disposição é ousada devido ao grande número de fotos - mais comum nas revistas ilustradas. Em relação à diagramação instaurada a partir dos anos 1950, mostra-se um pouco amadora no uso de textos não verbais em conjugação com os verbais: seis fotos são horizontais e apenas uma é vertical.

6 Pequenos artigos nos quais se procura orientar a opinião pública sobre os principais acontecimentos. 
A página apresenta quase um círculo de fotos e tal desenho, somado ao título, perfaz um todo dinâmico com movimento entre os seus vários elementos, convidando o olhar do leitor não apenas a lê-la, mas a percorrer a sua pulsação visual. Pulsação esta que revela dinamismo e agilidade, predicados fundamentais da modernidade: a tecnologia, a era das máquinas. Esses predicados que o jornal assimila a partir do desenho da página - texto não verbal - e se confirmam no texto verbal ao dialogar com as imagens.

O texto sinaliza ao leitor que, pela irrisória quantia de cem réis, é possível especificar o bom tipo de produto a ser adquirido: "é preciso que o typo seja bom, a revisão excellente, haja assumptos palpitantes, chronicas, artigos, um noticiário complettissimo, photogravuras, caricaturas - um mundo". A partir desses ingredientes básicos, a matéria indica que dos

jornaes do Rio de Janeiro, a "Gazeta de Noticias" é dos que acompanhando o movimento de informação europeu e norte-americano, primeiro nos tem dado e acostumado a todas essas novidades. Foi ella que fez o jornal barato, que iniciou as grandes collaborações, a caricatura instantanea, a interview, as enquetes, e até - a informação a cores. Pode-se dizer sem falsa modestia que a "Gazeta" não poupa sacrifícios em bem servir o publico.

Esse início demonstra a funcionalidade na prática de metajornalismo ao não apenas explicar como se faz um jornal moderno, mas ao tentar convencer o leitor de que a Gazeta de Notícias seria o melhor produto jornalístico da então capital federal. Tanto a variedade de temas e de abordagens quanto o uso de cores são destacados como elementos inovadores. Mais uma vez, a tentativa de conciliar as pujanças tecnológica e comercial, recorrente ao longo deste objeto midiático.

O primeiro bloco de intertítulo denomina-se "A reportage", o que inaugura várias outras expressões em língua inglesa referendando-se à matriz norte-americana: "A base do jornal moderno é a reportage". O jornal informa que todos os seus redatores são repórteres, exceto os plantonistas e o secretário. Todos "preparados para descrever um incendio como para escrever um artigo, logo após sobre o assumpto da actualidade". Também pontua que há repórteres setoristas para cobrir os segmentos ou repartições públicas "que mova o interesse publico".

Há outros tipos de repórteres para temas emergentes: o mundano, o esportivo, o das associações, o teatral, o das Casas do Congresso, o "commercial (creação da "Gazeta" no jornalismo carioca)" e o do operariado. Esse conjunto de definições de cobertura soma a este veículo a noção de linha de produção. A produção é segmentada e cada trabalhador realiza uma função específica em prol da montagem de um produto geral. O jornal diário deriva a especialização profissional como marca da modernidade, em contraste ao trabalhador mais artesanal, que ocupava todas as fases de feitura de um determinado produto.

O texto destaca que a "base principal desse primeiro aparelho e a reportagem de policia, que conta com reporters [...] conhecedores do 'bas fond' do Rio", ao cobrir desde 
o crime passional ao incêndio. "Quanto mais informações melhor" é a palavra de ordem deste jornalismo moderno. "A falta de um pormenor é considerada um 'furo' e a guerra da concorrência com os outros jornaes requer verdadeira diplomacia" (grifo nosso). Sinaliza a nova condição do jornalismo diário: produto comercial. A realidade de mercado, o da livre concorrência, é a verdadeira guerra cuja principal munição de ambas as partes é a "informação" mais apurada possível - guerra esta não apenas para ganhar espaços, como na convencional, mas para ganhar leitores e, por extensão, anunciantes.

O repórter de polícia é uma peça-chave e deve atuar como "detective' da propria policia, tem a sociedade e os seus segredos na mão, e trabalha-a a toda hora". Tanto no sentido amplo do repórter quanto no específico daquele que cobre a editoria de polícia, destaca-se a analogia ao detetive, como se a apuração jornalística não fosse apenas um paralelo à investigação policial em termos de procedimento profissional. Delimita-se a reportagem como auxílio à própria polícia, com o poder de vigiá-la. Na advertência discreta de que detém os segredos da sociedade, depreende-se as relações de poder entre o jornalismo e outros segmentos sociais. Esse paralelismo simbólico tem forte marca discursiva da época, quando o ato de reportar do jornalista era chamado de "diligência" e a reportagem de "investigação".

Após a descrição da reportagem, enfoca detalhes operacionais do cotidiano com enumeração de atividades com respectivos horários. É mais um indicativo como se está ante uma linha de produção, uma fábrica onde tudo é medido pelo tempo. "E o serviço continua então até a meia noite, com comunicações telephonicas, tilburys, automoveis desde que o assumpto mereça e a hora seja breve". Anexo à questão tempo, mantém-se o paradigma de velocidade com automóveis e comunicações telefônicas para complementar os modernos recursos somados a essa atividade.

No quesito redação, aposentou-se o antigo redator comum, cuja principal atividade seria de "enfeitar notícias e de reduzir notas de repórteres". Praticamente todos os envolvidos têm de estar habilitados a cumprir a apuração de dados. "Os redactores catam noticias tambem e a base dos seus artigos quando não é a reclamação para o bem publico, é sempre a informação".

Chega-se a desenhar um compromisso com a objetividade e a imparcialidade, mesmo não usando esses termos, o que viria a ser a chamada regra de ouro no jornalismo norte-americano da década de 1950. "A redacção, propriamente, a responsabilidade que harmonisa todas as opiniões e impersonalisa um typo único, todos os temperamentos, o jornal, é do redactor-chefe que dá a opinião".

O jornal informa que lança mão do recurso de aumentar o volume de "informação" - sempre essa prioridade como "correspondencias estrangeiras dos Estados, do serviço telegraphico que custa por anno uma fortuna". Nesse mesmo plano de custos, inserese a "informação visual" e explica-se: "os photographos apanham o caso sensacional, mandam ao gravador, se junta na redacção a prova [amostragem impressa em papel do clichê gerado] a noticia, enquanto a chapa desce para ser tirado ao bloco". 
O processo de narrar passo a passo a produção do jornal moderno continua na tipografia, na revisão e na estereotipia - onde se bate em papel especial os tipos que vão compor a página em chumbo derretido e tira-se o formato exato da página para inseri-la nas rotativas. Segundo a matéria, são tirados doze mil exemplares diários, a máquina de cinco cores produz 4,5 mil exemplares no mesmo espaço de tempo, havendo um total de quinze máquinas desse tipo na gráfica do jornal.

A apresentação pormenorizada dos números de tiragem e de máquinas modernas feita ao leitor destina-se a dar noção da pujança da empresa - fábrica de notícias de grande porte - e a valorizar o produto que ele consome por apenas "um nickel de bolso". Após todas essas etapas, os exemplares são dobrados e distribuídos ao enxame de "camelots" a gritar as manchetes para atrair compradores. Sendo essa outra novidade moderna no Rio de Janeiro, em muito moldada à imagem e semelhança das metrópoles europeias e norteamericanas: "Esses pobres diabos, alegres agitadores da rua, vieram depois das avenidas e dos automoveis e são o estonteante rumor dos carros, dos tramways, dos assobios das machinas, das cornetas dos autos".

\section{Diabos da atualidade}

Uma das marcas mais fortes do metajornalismo de João do Rio encontra-se nas discussões e nos questionamentos sobre a realidade da imprensa ao priorizar a condição de vida do repórter. O autor chega a abordar a questão na Gazeta de Notícias num dos espaços mais lidos, a sua coluna "Cinematographo", em 1º de setembro de 1907. O cronista "Joe" informou que o seu melhor amigo fez conferência na Associação Cristã de Moços para mais de oitocentas pessoas. João do Rio a fizera, anunciando ter "aberto o velário da miséria espantosa dos que são vistos por toda a gente e julgados felizes pelo mundo" (MAGALHÃES JUNIOR, 1978, p. 77).

João do Rio aponta aspectos do cotidiano do jornal não visíveis aos leitores ao denunciar o pagamento irrisório aos jornalistas.

O jornal é hoje uma empresa em toda a parte do mundo. Há empresas que pagam bem e outras que pagam mal. As latinas pagam mal. Deixamos de parte os proprietários. Estes arriscam capitais e responsabilidades aqui, num país que nem tem muitos jornais e não tem quinhentos mil leitores ao todo. Falemos dos que fazem os jornais e para os quais não há a menor complacência. [aqui o autor passa a citar os baixos salários - em cifras - de secretário de redação, redator] Já não há os redatores artísticos. Ainda restam os chamados teatrais. Mas estes hão de desaparecer, para dar lugar apenas à reclame paga [ou propaganda] pelo empresário mor causa dos oficiosos (MAGALHÃES JUNIOR, 1978, p. 77-78).

O jornalista continua informando exatamente quanto ganham os mais bem pagos na redação, os colaboradores diários, os "escritores aclamados": Rui Barbosa, 
Coelho Neto, Olavo Bilac, Medeiros e Albuquerque. Lembra que os pilares de um jornal são os telegramas das agências internacionais e a reportagem e chama a atenção com toque de humor - o fato de alguns repórteres terem atingido determinado grau de especialidade para o tipo de matéria que já respondia pela maior atenção do público leitor e vendagem dos exemplares:

\begin{abstract}
Uma notícia de suicídio tem mais leitores do que a crônica mais lavorada. O jornalista carioca tem um gênero em início: o das investigações e o das enquetes ${ }^{7}$, como as faz a Gazeta de Notícias. Nós temos repórteres capazes de ensinar ao mais esperto agente como se acha o fio de um crime [e volta a dar os números precisos do quanto mal pagos são]. Sim, há homens que são obrigados a usar gravata, colarinho, roupas decentes, que correm sem cessar buscando a nova de um acontecimento - bando lívido de caçadores de escândalos, tristes viajantes de curiosidades miúdas [...]. Em toda a parte as portas se fecham, com receio da indiscrição. Não importa. Como duendes, eles colam-se às fechaduras. São os diabos da atualidade. [...] Querem dar o furo, querem ser os únicos, desesperam-se, não dormem. Esse trabalho começa nos jornais da manhã ao meio-dia e termina regularmente às três horas da madrugada (MAGALHÃES JUNIOR, 1978, p. 80).
\end{abstract}

A receita de fazer jornal não mudou muito em relação ao jornalismo anterior, todos os dias era preciso estampar um escândalo. Só que a apuração faz toda a diferença para o interesse do leitor, desde um assassinato até a notícia sensacional. E o repórter? "Não têm futuro, senão na hora do dia seguinte". João do Rio lança a pergunta: "por que não fundarmos uma Associação de Imprensa?". A Associação Brasileira de Imprensa foi fundada em 7 de abril de 1908.

\title{
Da obscenidade no ato de reportar
}

A crônica "Profissões"8 é construída pelo processo de diálogo, apresentando-se como unidade cênica que quebra o ponto de vista único da narrativa. É possível perceber um dos vários momentos em que, ao longo de sua vasta produção, João do Rio constrói um texto de fronteira entre duas semiosferas, do jornalismo e do teatro - formado de um diálogo entre personagens que lembram a esquete.

De início, é um personagem não definido que se aproxima de uma mesa e interpela alguém que escreve. O primeiro pergunta ao outro o que faz, e este responde simplesmente "Trabalho". Aquele delimita o foco do questionamento ao indagar em que e recebe como resposta que escreve. Fica estabelecido o diálogo entre o desconhecido e aquele que escreve e a atividade do segundo será descortinada mais adiante.

7 Investigações (termo egresso do meio policial) era uma das denominações para as grandes reportagens temáticas, como "As religiões do Rio", e enquete especificava a grande entrevista com uma ou mais fontes, a exemplo de "O momento literário". A reportagem de campo era conhecida como diligência.

8 Publicada na Revista da Semana, em 20 de maio de 1916, sem paginação. 
O desconhecido afirma que, entre as "profissões" no Brasil, a menos reconhecida é a da escrita, julgada uma inutilidade. Assim como demonstrado na crônica anterior com a problematização sobre o pagamento que um repórter qualificado recebe. Tal aspecto volta em "A profissão de Jacques Pedreira" e em "A alma encantadoras das ruas".

Continuando a sua explanação, o personagem desconhecido afirma que, se alguém escreve, outros só se servem desse dom quando necessitam e até desenvolvem certo medo depois. Se o escritor mal exerce a sua função é pior, pois não tem medo nem antes nem depois. Para definir, bem ao estilo aforismático wildeano9: "A [profissão] de escrever corresponde ao enterro de ultima classe no Brasil" (RIO, 1916, s/p).

Ao correr do diálogo, o desconhecido afirma ser a imprensa "a grande e pathetica defeza dos outros" e os jornalistas estão sempre a trabalhar para os outros. "Elles são o socio para os idolos de um dia. Elogiando ou descompondo em politica servem os interesses d'outros". Ou seja, prende-se ao tempo do jornal diário. O leitor percebe que o trabalhador da escrita é um jornalista. Mesmo com o jornalismo moderno privilegiando a informação, o polemista deixa claro que a função da imprensa é ser uma caixa de ressonância de debates e polêmicas de sua sociedade, sempre a fazer a glória ou mesmo "descompor" alguém ou uma ideia - inviabilizando até a possibilidade real de insultos pessoais.

Na argumentação do desconhecido vê-se, mais uma vez, um procedimento discursivo recorrente na obra de João do Rio: demonstrar uma erudição para constantemente se legitimar junto ao seu público-alvo mais imediato: os segmentos de classe dominante. Algo bem parecido com o refinamento wildeano em uma de muitas atitudes paradoxais. Apesar de apresentar-se como extremamente moderno, tem a necessidade de mostrar o quanto é fundamental dominar tradições anteriores. Nesse caso, o desconhecido exemplifica uma gradação neste atacar ou elogiar constantes dos jornalistas:

Uns são macios, outros são ferozes, anda outros como Martial, são conforme a paga. Mas Martial apesar das suas baixezas morreu pobre, e Aretino não tinha a fortuna de qualquer secretário de administrador com fama de honesto. A paga é sempre ridicula em relação ao serviço. Em geral não existe (ibidem, s/p).

O que está em jogo é um determinado momento de uma polêmica ampla e longa da qual João do Rio participou, pelo menos desde a crônica citada acima, de 1907, sobre as condições de produção e de pagamento aos profissionais da imprensa.

Para alavancar esse questionamento, João do Rio lança mão de duas figuras históricas. Marco Valério Marcial (c. 38 d.C.- c. 104), poeta que expressou em seus epigramas com ironia e mesmo obscenidade - o cotidiano e as fraquezas da sociedade romana da época e Pietro Aretino (1492-1556), poeta e jornalista nascido em Arezzo (atual Itália)

9 A obra de Oscar Wilde tem em João do Rio um de seus mais disseminadores na primeira república (FARIA, 1988, p. 82). Apenas de traduções, a peça teatral Salomé - primeira edição em 1905 pela Revista Kosmos e, em livro, em 1908 -, a coletânea de ensaios Intenções (1911) e o romance O retrato de Dorian Gray (1923). 
e conhecido por seus versos mordazes e também obscenos. Também se destacou ao publicar críticas ácidas no Pasquino romano, em Delle Lettere (1538-1557), e trazendo a linguagem popular na literatura.

Ambos foram jornalistas nas suas respectivas épocas e ficaram mais conhecidos por suas produções ditas pornográficas. Porém, mais apropriadamente identificáveis como obscenas, em seu original sentido etimológico latino - aquilo que está fora de cena. Ambos traziam para a cena o que não tinha visibilidade. Para muitos, o que eles diziam nem sequer existia até o momento em que se corporificara em determinada escrita. Muito além do movimento pendular de atacar ou elogiar, o ato de reportar é justamente trabalhar com a dualidade cena/ fora de cena. Dar visibilidade ao que não é visto pela plateia, pela sociedade. O jornalismo sempre é um ato obsceno, independente dos padrões morais de espaço e tempo.

A partir da afirmação de que os jornalistas são como "malabaristas de projeção dos outros" - identificação em evidente metáfora alusiva ao cinematógrafo - o personagem desconhecido propõe que os jornalistas não servem a uma entidade social, a pátria. Essa declaração, um tanto prosaica aos olhos de hoje, tinha lastro de pressuposição com os leitores. Em plena Primeira Guerra Mundial, surgiram várias campanhas nacionalistas sendo uma das mais famosas a série de conferências pelo Brasil incrementadas por Olavo Bilac. Em dimensão menor, João do Rio também fez palestras do mesmo tipo.

A crônica tem final de profunda ironia. Após toda uma linha de raciocínio transitando entre o irônico e o cético sobre a atividade jornalística, o desconhecido tenta "cavar" favor do jornalista. "- A proposito. Vaes fazer-me um favor. É possível publicar um retrato deste amigo a quem devo obrigações? Mas com algumas palavras tuas. Só tuas. Porque talento só tu..." (ibidem, s/p). O desconhecido, após breve diálogo, já se sente à vontade para falar em tom impositivo com quem há pouco conheceu, "vaes fazer-me". Ele ameniza logo o tom da sequência ao perguntar se "é possível", mas fica clara a postura arrogante. Em troca desse favor, ele retribui apenas com um elogio ao ego do jornalista sobre o seu "talento". Como apontamos anteriormente, enfatiza-se justamente que a paga ao jornalista é ridícula ou inexiste.

\section{Pensar o futuro?}

Como recentemente lembrou um dos mais importantes jornais da América Latina, o argentino La Nación, estamos em nova e imprevisível era com o advento do jornalismo digital. Ficam as perguntas: "Há futuro para os jornais diários?" e "Qual o lugar dos jornalistas nessa nova ordem midiática?".

En los últimos diez años, 130 diarios de Estados Unidos han desaparecido. El Jornal do Brasil, fundado en 1891 en Río de Janeiro, ha suprimido su edición en papel al igual que el bostoniano Christian Science Monitor, y el tradicional Evening Standard ya se entrega de manera gratuita por las calles de Londres. 
El Foro Mundial de Editores de Prensa pronósticó que en los próximos cinco años las ventas de los diarios sufrirán un descenso del $50 \%$ y que más de la mitad de los lectores consumirá los contenidos a través de las ediciones on line. Es evidente que la transición está en marcha, pero resulta difícil saber hacia dónde se avanza (TARIFEÑO, 21 de out. 2011).

O quadro apresenta outras complicações no caso brasileiro. Com a década de 1980, mais conhecida eufemisticamente como a de "crescimento zero", viveu-se um enxugamento drástico e constante de postos de trabalhos nas redações. Crescentes levas de demissão aconteciam tanto pelo lado econômico, queda de anunciantes, quanto pela crescente informatização que aboliu várias funções da linha de produção. A internet trouxe uma bolha com novas mídias na década de 1990 que não demorou a estourar.

Viveu-se e vive-se uma séria exclusão de trabalhadores nesse pulo da era analógica à digital. A ponto de veículos, como o Jornal do Brasil, a revista PCWorld, entre outros, só existirem em versão digital.

Outro impasse foi a desregulamentação da profissão de jornalista. A regulamentação foi uma luta que começou na primeira década do século passado. Não à toa, a grande ênfase da Gazeta de Notícias, em 1907, sobre o jornal moderno da época eram o repórter e o avanço tecnológico. João do Rio, no mesmo ano, polemiza com o mesmo jornal onde atuava ao expor ao leitor o desconhecido: de como essa mão de obra se qualificou e muito, mas continuava a ter um salário miserável. Essa manifestação não foi isolada. Estava inserida na luta pela regulamentação da profissão e por melhores condições de trabalho e remuneração. Um importante momento dessa trajetória foi a fundação da ABI em 1908 para encampar esse movimento.

Em resumo e salvaguardando as proporções, hoje os jornalistas estão quase como há cem anos no Brasil.

Ouvir estas e outras vozes da época, como aludimos, é importante para construir uma memória esquecida sobre esta atividade profissional e o destino dos veículos de comunicação para melhor pensar esta realidade hoje e tentar projetar o futuro.

Gutemberg Medeiros é jornalista e doutor em ciências da comunicação pela ECA-USP; é pesquisador do Grupo de pesquisa Núcleo de Estudos do Livro e da Edição da ECA/USP

gam8@terra.com.br 


\section{Referências}

CARVALHO, Elysio de. Ensaios. Brasília: Fundação Casa do Penedo: Universa, 1997.

CARVALHO, José Murilo de. Os bestializados: o Rio de Janeiro e a república que não foi. São Paulo: Companhia das Letras, 1989.

COMO SE FAZ um jornal de hoje. In: Gazeta de Notícias, Rio de Janeiro, 2 agosto 1907.

FARIA, Gentil de. A presença de Oscar Wilde na "belle époque" literária brasileira. São Paulo: Pannartz, 1988.

JOBIM, Danton. Espírito do jornalismo: o fenômeno do jornalismo na cultura brasileira. Rio de Janeiro: Livraria São José, 1958.

LECLERC, Max. Cartas do Brasil. Tradução, prefácio e notas de Sérgio Milliet. São Paulo: Companhia Editora Nacional, 1942.

LIMA SOBRINHO, Barbosa. A Imprensa. In: DOYLE, Plínio (Org.). Brasil 1900-1910. Rio de Janeiro: Biblioteca Nacional, 1980. p. 123-141.

LOTMAN, luri. La Semiosfera. Madrid: Ediciones Cátedra, 1996.

MAGALHÃES JUNIOR, Raymundo. A vida vertiginosa de João do Rio. Rio de janeiro: Civilização Brasileira, 1978.

MEDEIROS, Gutemberg Araújo de. Urbanidade e metajornalismo nas matrizes da modernidade: memória textual nas produções de Lima. Barreto e João do Rio no início do século XX. (Tese de Doutorado). Escola de Comunicações e Artes na Universidade de São Paulo, 2009.

OLIVEIRA, Maria Madalena da Costa. Metajornalismo... ou quando o jornalismo é sujeito do próprio discurso. (Tese de Doutorado). Instituto de Ciências Sociais da Universidade do Minho, 2007.

RIBEIRO, Leo Gilson. O Sol sobre o pântano. In: RODRIGUES, Nelson. Teatro quase completo: volume IV. Rio de Janeiro: Tempo Brasileiro, 1966.

RIO, João do. Profissões. In: Revista da Semana, 20 maio 1916, s.p.

RODRIGUES, João Carlos. João do Rio: uma biografia. Rio de Janeiro: Topbooks, 1996.

TARIFEÑO, Leonardo. Los caminos del periodismo. In: La Nación, 21 outubro 2011. Disponível em: <http://www.lanacion.com.ar/1415735-los-caminos-del-periodismo>. Acesso em: 10 nov. 2011.

Artigo recebido em setembro e aprovado em dezembro de 2012. 


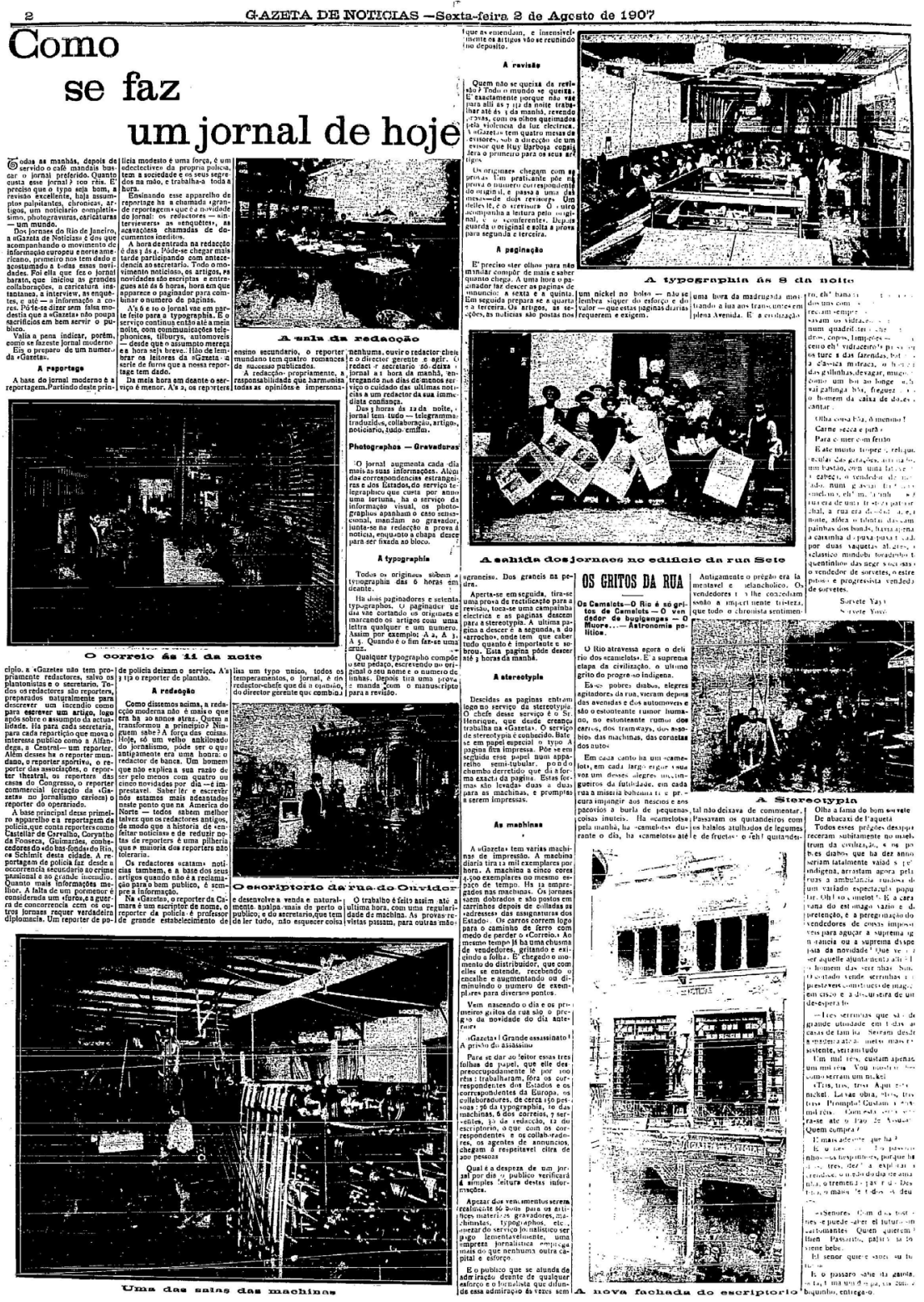




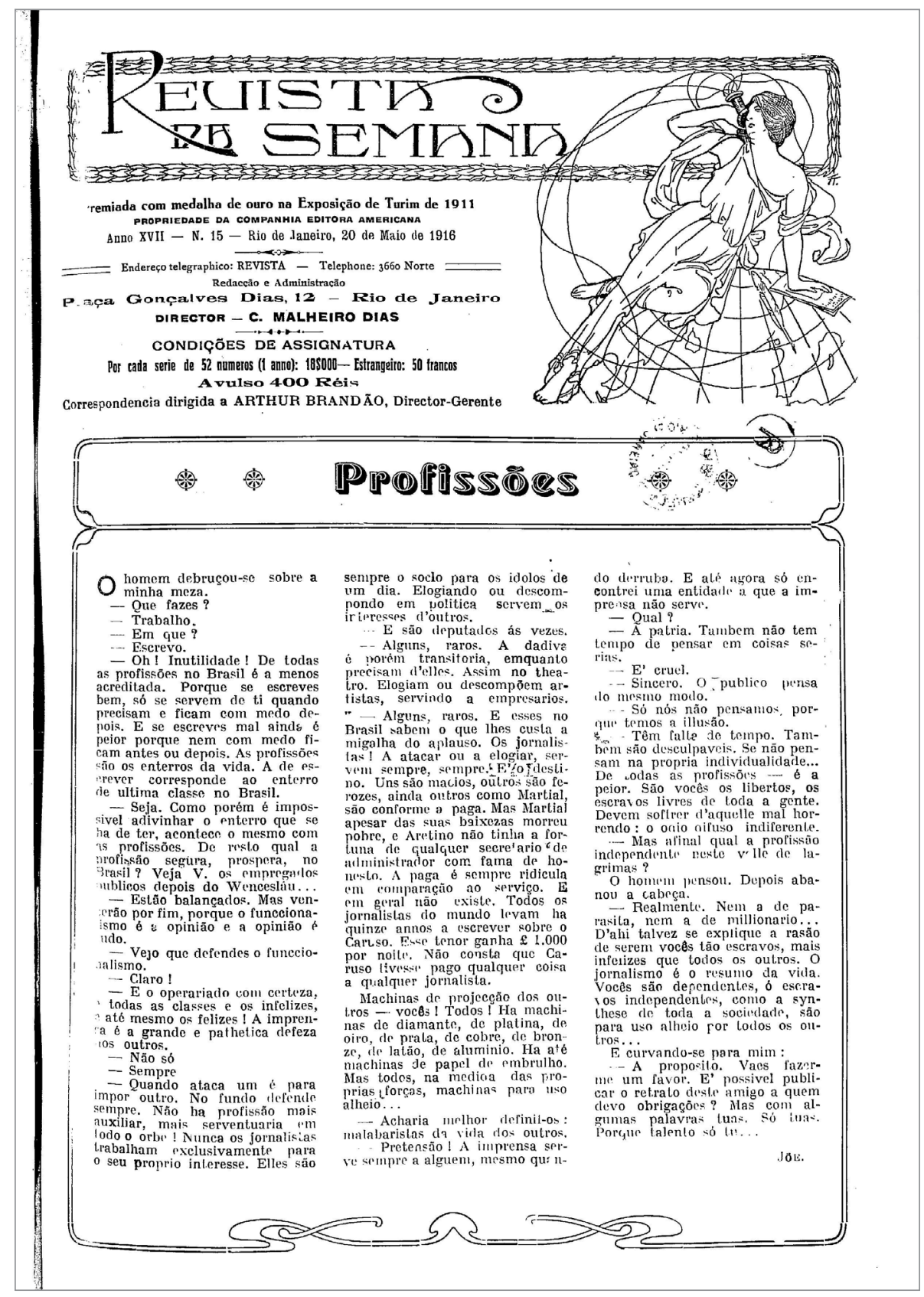

